\title{
Kunstpædagogisk teori og praksis i et didaktisk perspektiv ${ }^{1}$
}

HELENE ILLERIS*

\begin{abstract}
The application of curriculum theory to museum practice affords a way to embrace shifting notions about knowledge and to make them central to the work of education. (Roberts 2006: 77)
\end{abstract}

Title: Gallery education in theory and practice. A curriculum perspective. Abstract: This article presents a critical study of the relationship between theory and practice in the field of gallery education, within a conceptual framework borrowed from American curriculum theory from the 1970s. Inspired by Elliot Eisner's and Elisabeth Vallance's book Conflicting Conceptions of Curriculum (1974), the article individuates four conceptions within contemporary gallery education, presented within two models: 1. Gallery education based on theories of aesthetic experience, 2. gallery education based on theories of learning and cognition, 3. gallery education based on theories of curriculum and 'bildung' 4. gallery education based on theories of social critique and change.

In the second part of the article, each of the four conceptions is exemplified via a systematic analysis of two contemporary Nordic or British texts on gallery education. Studies and discussions of the relationships between theory, goals and proposals for educational practices within each of this total of eight texts allow the author to argue for more precise curriculum-based reflections within Nordic gallery education practice.

Key words: Gallery education, curriculum studies, aesthetic experience, learning, bildung, social critique.

INDLEDNING: DET DIDAKTISKE PERSPEKTIV

Inden for pædagogik som videnskab anvendes begreberne didaktik og curriculum om to delvis overlappende discipliner, der begge har at gøre med forskning i undervisning og læring:
Det tysk/nordiske begreb "didaktik" har traditionelt omhandlet planlægning og gennemførelse af undervisning med fokus på mål og indhold, mens det angelsaksiske "curriculum" har fokuseret mere på design og evaluering af læreplaner baseret på forskning i læreprocesser 
HeLene ILleris

30 (Nielsen 1998:19 ff.; Schnack 2000). Siden 1970'erne har begge discipliner udvidet deres interessefelter til at omhandle et bredt spektrum af problemstillinger inden for undervisning og læring i relation til bl.a. psykologiske og samfundsmæssige spørgsmål. For ikke at komplicere argumentationen yderligere, vil jeg derfor fremover i artiklen fortrinsvis vil anvende begrebet "didaktik", også når jeg tager udgangspunkt i engelske og amerikanske tekster.

En anden vigtig problemstilling angår, hvad Frede V. Nielsen definerer som "didaktikkens to virksomhedsformer" og samspillet mellem disse. Begrebet betegner nemlig både en videnskabeligt orienteret, teoretisk virksomhed ("didaktik som læren om”...) og en undervisningsorienteret, praktisk virksomhed ("didaktik som planlægning af og beslutning vedrørende"...) (Nielsen 1998: 23 ff.). Inspireret af bl.a. Pierre Bourdieu (1993) John I. Goodlad (1979) vælger jeg at definere "didaktik" endnu bredere, nemlig som et praksisfelt, der omfatter alle de teoretiske og praktiske virksomhedsformer, hvor igennem undervisning og læring defineres, studeres, problematiseres, rammesættes, planlægges, udføres, erfares og reflekteres.

Som didaktisk rammeværk for undersøgelserne i denne artikel vil jeg anvende to amerikanske tekster fra 1970'erne, som begge var med til at problematisere tidligere og mere snævre didaktik-forståelser: Elliot Eisner og Elisabeth Vallances Conflicting Conceptions of Curriculum (1974) og John I. Goodlads Curriculum Inquiry. The Study of Curriculum Practice (1979). Den første tekst er primært teoretisk orienteret. Her bestemmes, med udgangspunkt i tekster af fremtrædende amerikanske pædagogiske tænkere som Phillip H. Phenix og Joseph H. Schwab, fem didaktiske konceptioner, hvoraf jeg i det følgende anvender de fire som inspiration til en overordnet kategorisering grundlæggende teoretiske tilgange til kunstpædagogik på museer. ${ }^{2}$

Den anden tekst udgør et centralt bidrag til udviklingen og konceptualiseringen af de forskellige aspekter, som tilsammen udgør den undervisningens praksisfelt. Goodlad definerer her "Curriculum inquiry" som det empiriske studium af didaktisk praksis, ikke blot forstået som undersøgelser af faktisk forekommende undervisning, men forstået som samspillet mellem fem forskellige kategorier af "læreplaner": idemassige lereplaner, formaliserede lareplaner, perciperede lareplaner, operationaliserede lareplaner og erfarede lareplaner. ${ }^{4}$ Med afsæt i disse kategorier er Goodlad optaget af, hvorledes man empirisk kan studere sammenhængen mellem teoretisk og politisk informerede intentioner og målsætninger (idemæssige læreplaner), forskrifter og konkrete forslag til undervisningsforløb (formaliserede læreplaner), lærernes opfattelse af, hvorledes dette skal omsættes i praksis (perciperede læreplaner), faktisk observerbar undervisning (operationaliserede læreplaner) samt endelig elevernes oplevelser af undervisningen og deres eget læreudbytte (erfarede læreplaner). ${ }^{5}$ Goodlads mål er at producere viden om, hvad der sker når forskellige typer af målsætning konkretiseres i faktisk undervisning, men uden at tabe af syne, at også "undervisning" må forstås som et komplekst felt, der indeholder en række forskellige forståelser og positioner.

\section{NORDISK KUNST- OG MUSEUMSPFEAGOGIK MELLEM TEORI OG PRAKSIS}

Med nærværende artikel ønsker jeg at anlægge et kritisk, didaktisk perspektiv på forholdet mellem teori og praksis på det kunstpædagogiske felt. ${ }^{6}$ Inden for kunst- og museumspæda- 
gogikken er empiriske undersøgelser af forskellige teorier og programmers didaktiske implikationer fortsat forholdsvis sjældne. Som tidligere påpeget (Illeris 2005: 61 ff.), har nordiske forskere inden for en række områder en stor teoretisk interesse for museumspædagogik. Forskningen er dog kun i begrænset kontakt med museerne, som udgør et forholdsvis uafhængigt praksisfelt, hvor de enkelte formidlere og formidlingsansvarlige som oftest udvikler pædagogiske målsætninger og forløb ud fra egen erfaring, gerne kombineret med et ad hoc kendskab til museumspædagogisk teori. Kun i enkelte tilfælde ses længere samarbejder mellem museumspædagogiske teoretikere og museer. ${ }^{7}$

Museumspædagogiske forskere har løbet af de sidste 10-20 år produceret flere væsentlige analyser af de forskellige forståelser, der har ligget til grund for udviklingen af praksis. Blandt de mest kendte kan nævnes Eilean Hooper-Greenhill: Museum and Gallery Education (1992), Lisa C. Roberts: From Knowledge to Narrative (1997), og George E. Hein: Learning in the Museum (1998). Jeg har desuden fundet en håndfuld engelsksprogede artikler, der kobler museumspædagogik og didaktik ( $\mathrm{fx}$ Vallance 2004, 2006; Rose 2006). Ingen af disse fokuserer dog specifikt på kunstmuseer, hvorimod jeg i den skandinaviske litteratur har fundet flere eksempler på didaktisk orienterede kunstpædagogiske tekster. Af større afhandlinger kan bl.a. nævnes Anna Lena Lindberg: Konstpedagogikens dilemma (1991) og Arne
Marius Samuelsen: Kunstformidling for barn $i$

\section{KUNSTPÆDAGOGISKE KONCEPTIONER - TO MODELLER}

Karakteristisk for flertallet af de ovenfor nævnte tekster er, at de optegner en genealogi, hvor hidtidige (og fortsat aktive) positioner trækkes op for derefter at komme med forslag til en mere aktuel didaktisk forståelse. I kontrast hertil søger denne artikel at anlægge et synkront perspektiv gennem alene at fokusere på nutidige forståelser. Med inspiration fra Eisner og Vallance (1974) indkredser artiklen fire aktuelle kunstpædagogiske konceptioner:
1. Kunstpadagogik baseret på teorier om astetisk oplevelse

2. Kunstpadagogik baseret på teorier om laring og kognition

3. Kunstpadagogik baseret på teorier om didaktik og dannelse

4. Kunstpedagogik baseret på teorier om social kritik og forandring

For at skabe et overblik over disse, har jeg lavet to forslag til modeller, som kan placere konceptionerne $\mathrm{i}$ forhold til hinanden inden for hhv. et kontinuum og en mere kompleks (om end fortsat stærkt forenklet) rumlig præsentation. I kontinuum-modellen er konceptionerne placeret på en linje med den mest individuelt orienterede, baseret på æstetisk oplevelse, længst til venstre, og den mest kollektivt orienterede, baseret på social kritik og forandring, længst til højre:

\begin{tabular}{|llll|}
\hline $\begin{array}{l}\text { æstetisk } \\
\text { oplevelse }\end{array}$ & $\begin{array}{l}\text { læring og } \\
\text { kognition }\end{array}$ & $\begin{array}{l}\text { didaktik og } \\
\text { dannelse }\end{array}$ & $\begin{array}{l}\text { social kritik } \\
\text { og forandring }\end{array}$ \\
${ } }$ & KOLLEKTIV ORIENTERING \\
\hline
\end{tabular}


HeLENE ILLERIS

32

\begin{tabular}{|c|c|c|}
\hline $\begin{array}{c}\text { Fstetisk } \\
\text { oplevelse }\end{array}$ & $\begin{array}{c}\text { Læring og } \\
\text { kognition }\end{array}$ & $\begin{array}{c}\text { Individuel } \\
\text { orientering }\end{array}$ \\
\hline $\begin{array}{c}\text { Social kritik } \\
\text { og forandring }\end{array}$ & Didaktik & $\begin{array}{c}\text { Kollektiv } \\
\text { orientering }\end{array}$ \\
\hline $\begin{array}{c}\text { Læring som } \\
\text { overskridelse }\end{array}$ & $\begin{array}{c}\text { Læring som } \\
\text { erkendelse }\end{array}$ & \\
\hline
\end{tabular}

I den mere rumlige model har jeg desuden ordnet konceptionerne efter om de primært er orienteret mod et $\mathrm{i}$ forvejen accepteret og etableret læringsindhold ( $\mathrm{fx}$ at lære om kunst eller om at se på kunst i bred forstand), eller om de er orienteret efter en overskridelse af almindeligt anvendte målsætninger med henblik på at skabe helt ny og uforudsigelig viden (fx om sig selv, om fællesskabet eller om kunsten):

Jeg anvender modellerne i min overordnede karakteristik af de enkelte konceptioner, samt i analyserne af de enkelte tekster, for på den måde at præcisere forskellighederne i deres didaktiske perspektiv. Jeg vil samtidig gerne understege at disse modeller naturligvis udgør et meget forenklet billede af virkeligheden, idet samtlige de beskrevne teorier og praktikker inden for de enkelte konceptioner på forskellig vis netop er optaget af at indfange relationerne mellem individuelt og kollektivt, erkendelse og overskridelse. Modellerne angiver altså tendenser og retninger og ikke absolutte kategoriseringer.

\section{EMPIRISK MATERIALE: VALG AF TEKSTER}

Artiklen bygger på læsninger af otte eksempler på aktuelle kunstpædagogiske tekster fra Danmark, Norge og Storbritannien med henblik på at analysere samspillet mellem a) tekstens teoretiske udgangspunkt (den kunstpædagogiske konception), b) den overordnede kunstpædagogiske målsatning, som kommer til udtryk i teksten (den idemæssige læreplan) og c) et foreslået eller gennemført undervisningsforløb, som præsenteres som eksemplarisk i forhold til målsætningen (den formaliserede og/eller operationaliserede læreplan). Teksterne har til fælles, at de er skrevet inden for de sidste 10 år; at de søger at kombinere en teoretisk forståelse med en mere konkret målsætning og i de fleste tilfælde et tænkt eller realiseret undervisningsforløb; og sidst men ikke mindst, at jeg finder dem nogenlunde repræsentative i forhold til de ovennævnte kunstpædagogiske konceptioner.

Det har ikke været let at finde et udvalg af tekster som opfyldte disse kriterier, hvilket også har gjort at jeg har måttet foretage en række kompromisser. Som de væsentligste kan nævnes: Jeg har i mange tilfælde måttet sammensætte "min" tekst af flere tekster af sam-me forfatter, typisk en teoretisk tekst og en praksisrelateret tekst. Nogle tekster savner eksempler 
på afsluttede undervisningsforløb, mens en enkelt savner tydelige teoretiske referencer, derfor har jeg i disse tilfælde måttet "nøjes" med at analysere forfatternes præsentation af delforløb, eller jeg har måttet referer til begrebsbrug snarere end egentlige teoretiske referencer. Endelig bruger jeg, af mangel på bedre, i to ud af otte tilfælde tekster, jeg selv har skrevet.

\section{FØRSTE KONCEPTION: KUNSTPÆDAGOGIK BASERET PÅ TEORIER OM ÆESTETISK OPLE- VELSE}

Strongly and deliberately value saturated, this approach refers to personal purpose and to the need for personal integration, and it views the function of the curriculum as providing personally satisfying consummatory experiences for each individual learner. It is child centered, autonomy and growth oriented, and education is seen as an enabling process that would provide the means to personal liberation and development. (Om konceptionen Self-actualization or Curriculum as Consummatory Experience, Eisner og Vallance 1974: 9)

Kunstpædagogik baseret på teorier om æstetisk oplevelse har fokus på individuelle møde mellem beskuer og værk. Didaktisk handler denne kunstpædagogiske konception derfor om at iscenesætte de bedst mulige betingelser for, at dette møde kan finde sted og for, at det kan få den intenst engagerende kvalitet, som er nødvendig for den æstetiske oplevelse. Målsætningen er udpræget transformativ, idet mødet i sidste instans drejer sig om at opnå transcenderende bevidsthedstilstande, der fører til personlig udvikling i retning af øget selvindsigt, større åbenhed og følelsesmæssig modenhed. Der er altså ikke tale om, at eleverne skal lære at beherske viden og færdigheder $\mathrm{i}$ traditionel forstand, men snarere om en udviklende og frigørende effekt, som knyttes an til kunstværkers særlige potentiale som værende på en gang mangetydige og eksistentielt orienterede.

\section{EKSEMPEL 1: BøRN I NÆRKONTAKT MED KUNST}

I artiklen Børn i norkontakt med kunst (Funch et al. 2009) præsenterer en gruppe forskere og formidlere et større eksperimenterende formidlingsprojekt $4 a$ - mellem musik og billedkunst, som fandt sted på Esbjerg Kunstmuseum i skoleåret 2006-2007.

Projektet berørte kun en enkelt 4. klasse, som til gengæld blev undervist skiftevis på museet, på Vestjysk musikkonservatorium og på skolen gennem et helt år.

Teori: Det teoretiske afsæt for projektet ligger i kunstpsykologen Bjarne Sode Funchs mangeårige arbejde med udviklingen af "æstetisk oplevelse" som et psykologisk begreb, der alene har at gøre med oplevelse af kunstværker, fordi disse i modsætning til $\mathrm{fx}_{\mathrm{x}}$ andre typer af flowoplevelse som sport og leg, berør eksistentielle temaer (Funch 1996: 204). Ud fra en eksitentielt-fænomenologisk forståelse forklarer Funch det unikke ved den æstetiske oplevelse af kunst med, at der er tale om en oplevelse af specifik transcendent karakter, hvor en hidtil ukonstitueret emotionel kvalitet hos betragteren, pludselig, via et bestemt kunstværk, bliver forsynet med en "adækvat og distinkt form" (ibid.: 242).

Målsetning: I det aktuelle projekt er målsætningen arbejdes dels med nogle overordnede formål, herunder" ... at etablere en indstilling til kunst, hvor børnene involverer sig på et psykologisk niveau","... at etablere en sensivitet over for det samspil der kan være mellem kunst og betragter” og mere generelt at opnå” 
$34 \quad \ldots$ en psykisk tilstand, der er grundlæggende for åbenhed" (Funch et al. 2009: 4-5). Særlig fokus er dog på udvikling af "visuel sensivitet" og "emotionel intonation", hvor førstnævnte er en opmærksomhed overfor kunstværkets visuelle fremtrædelsesform, kombineret med forståelse for egen emotionelle reaktion, mens sidstnævnte er en"... kapacitet til at leve sig ind $i$ et kunstværk på en sådan måde, at det emotionelle træder frem og bliver en betydningsfuld del af oplevelsen" (ibid.). Gennem eksempler fra interviews med børnene dokumenterer forfatterne, hvorledes deres visuelle sensitivitet og emotionelle intonation bliver styrket gennem deltagelse i undervisningsprogrammet.

Forløb: Selve programmet er delt op i en række delforløb over året. I det indledende delforløb vælger hvert barn selv et kunstværk, som hun eller han gerne vil beskæftige sig med gennem hele forløbet (dog med mulighed for at foretage omvalg). Dette værk står herefter i centrum for en række aktiviteter, som skal give børnene en stærkere tilknytning til værket, bl.a. at udvælge musikstykker til værket og spille dem for hinanden, at arbejde med billeddialoger, samt at skrive tekster til værkerne og lave tegninger af dem ud fra hukommelsen. Siden hjælper musikere børnene med at overføre deres kunstoplevelse til musik, og de fortolker værkerne gennem musik og dans under vejledning af danser, og endelig arbejdes med lydsætning, rap-musik, portrætter, abstrakte selvportrætter, lydportrætter, digte og fortællinger.

\section{EKSEMPEL 2: Det FABULERENDE KUNSTMØDE}

Den norske forsker Guri Lorentzen Østbye introducerer i sin bog Barn + Kunst $=$ Dan- ning (2007) "det fabulerende kunstmøde". En væsentlig pointe ved dette møde er, at danne et "undrende og fabulerende fællesskab", hvor eleverne, gennem visuel opmærksomhed og struktureret refleksion, gives mulighed for dels at udvikle og praktisere en personlig tilgang til oplevelsen af et kunstværk, dels for at deltage fælles meningskonstruktioner.

Teori: Østbyes tekst udgår fra et dannelsesteoretisk fundament, hvor begrebet "æstetisk erfaring" står centralt, idet det, med inspiration fra filosofferne John Dewey og Lars Løvlie, anvendes dels om en umiddelbar, exceptionel oplevelse, dels om en eksperimenterende, udforskende og grænsesprængende proces (Østbye 2007: 50). I modsætning til Dewey, der beskriver æstetik som en særlig kvalitet ved allehånde oplevelser/erfaringer, mener Østbye, at møder med kunstværker i særlig grad virker befordrende for æstetisk oplevelse, fordi de viser os det "diskursivt uudsigelige" som giver anledning til en erkendelsesvirksomhed, hvor deltagerne i mødet så at sige skaber sig selv på ny i en kontinuerlig dannelsesproces (ibid.: kap. 2).

Målsatning: Østbyes bog er usædvanlig rig på overordnede intentioner, begrundelser og målsætninger. En del af målsætningerne er fokuseret på at opnå en overordnet og varig personlighedsudviklende effekt med "bevidstgørelse", "øget selvindsigt", "mod til at gå ind i det ukendte" og "udvikling af følelsesbaseret sympati", som nogle af omdrejningspunkterne (ibid.: 179 ff.). En anden del omhandler udviklingen af et demokratisk sindelag med fokus på bl.a. respekt for den Anden og tolerance gennem opmærksomhed overfor mangfoldigheden af individuelle tolkningsmuligheder i værkerne (ibid.: 166).

Forløb: Østbyes bog indeholder flere eksempler fra egen og andres undervisning, samt 
et bud på en "procedure", som i særlig grad egner sig til at stimulere "fabulerende" kunstmøder (ibid.: 151 og 173). Proceduren tager sig i forenklet form ud som følger: Først præsenterer læreren/formidleren kunstværket ved at give nogle faktuelle oplysninger om kunstværket, men det understreges, at denne bør være kortest mulig ".. for å unngå å fungere ledende med hensyn til hva barna vil se etter" (ibid.: 173). Herefter kommer oplevelsesfasen, som kort beskrives som en "se- og tenkepause" (ibid.: 172). I refleksionsfase 1 formulerer børnene i skrift eller på anden måde deres individuelle refleksioner i en logbog, mens de i refleksionsfase 2 inviteres til at præsentere et udsagn eller et tema, som de ønsker at dele med de andre i gruppen. Refleksionsfase 3 er til fælles refleksion, fx over et af de spørgsmål eller temaer som kom frem under fase 2. Endelig foreslås en mulig viderebearbejdning fx i form af leg og dramatisering, men dette uddybes ikke i teksten.

\section{DISKUSSION}

Fælles for de to eksempler er, at de ser mødet mellem betragter og kunstværk som et eksistentielt orienteret møde mellem to afgrænsede parter: et unikt selv og et unikt værk. Hermed knyttes an til modernistiske forståelser om "kunst" som værende bestemt ved besjælede og i bund og grund selvformidlende værker og om "mennesket" som indeholdende et "selv", som kan realiseres i større eller mindre grad, alt efter i hvor høj grad oplevelses- og erfaringsprocesserne formår at skabe eller konstituere dette selv.

Målsætninger som "emotionel intonation" og "følelsesbaseret sympati" indikerer, at æstetisk oplevelse i høj grad har med følelser at gøre og begge eksempler understreger kunst- mødets helt særlige betydning for udviklingen af følelseslivet. I modsætning til Deweys forståelse af aesthetic experience som noget der først og fremmest angår oplevelsens kvalitet (uanset om der er tale om en kunstoplevelse eller ikke), fremhæves kunstværker som havende helt unikke didaktiske oplevelsespotentialer.

Set i forhold til artiklens indledende didaktiske modeller er denne kunstpædagogiske konception præget af at være meget ambitiøs omkring mødets iboende kvaliteter som didaktisk værktøj i elevernes individuelt orienterede, selvskabende og selvoverskridende proces. Hvad mødets øvrige positioner angår, er disse til gengæld meget svagt tegnet op. Museet som institution og fysisk omgivelse, ophængningens og undervisningens eventuelle tema og tilstedeværelsen af en formidler/lærer forekommer næsten at være forstyrrende elementer i forhold til det "rene" møde mellem værk og betragter. Desuden er det typisk for denne konception, at den pointerer eksistentielle tilgange med vægt på fælles menneskelige oplevelsesformer, hvorimod individuelle og kollektive forskelle blandt elever og lærere, fx i forhold til køn, alder, social baggrund m.v. ikke tematiseres.

\section{ANDEN KONCEPTION: KUNSTPÆEDAGOGIK BASERET PÅ TEORIER OM LÆERING OG KOGNI- TION}

[...] the cognitive process approach sees the learner as an interactive and adaptive element in a system which, if given the correct intellectual tools, could grow almost indefinitely. The problem of the educator and curriculum specialist, then, is to identify the most salient and efficient intellectual processes through which learning occurs and to provide the setting and structure for their development. (Om Curriculum as 
HELENE ILLERIS

the Development of Cognitive Processes, Eisner og Vallance 1974: 6)

Denne type kunstpædagogiske konceptioner er karakteriseret ved at være optaget af hvordan eleverne lærer, og af at tilrettelægge optimale læreprocesser. Målet med læringen problematiseres i mindre grad, fordi det her er vejen til målet, snarere end indholdsmæssig nytænkning, som er i fokus. Gennem læring og kognition studeres og iscenesættes optimale tilegnelsesprocesser af de vidensformer, museet og kunsten repræsenterer, uden at der grundlæggende skabes tvivl om, eller overskridelse af, disse.

Inden for museologi og museumspædagogik generelt har læring været et helt centralt begreb siden det "paradigmeskift" der skete 1980'erne og 1990'erne, hvor en overvejende behavioristisk-positivistisk tilgang gradvist blev erstattet af en konstruktivistisk-relativistisk opfattelse, der satte den lærende snarere end læringens indhold i centrum (Adams et. al. 2003: 16). Endvidere kan man pege på, at man inden for den konstruktivistisk-relativistiske opfattelse har bevæget sig fra at være optaget af individuel læring, $\mathrm{fx}$ inspireret af Jean Piagets kognitive udviklingsstadier eller Howard Gardners teori om de mange intelligenser, til et stigende fokus på kollektivt orienterede, sociokulturelle læringsteorier, inspireret af bl.a. den russiske kulturhistoriske skole, og dennes aktualisering i nutidig pædagogisk teori (Insulander 2005).

I Danmark er ikke mindst George Heins læringsmodel, som udgår fra den konstruktivistiske og individuelt orienterede tese ".. that knowledge is constructed in the mind of the learner" (Hein 1998: 156) og John H. Falk og Lynn D. Dierkings kontekstorienterede model, som skelner mellem læringens personlige, fysiske og sociokulturelle kontekst (Falk og Dierking 2000: 12) blevet anvendt i flere formidlingsprojekter og universitetsopgaver (se fx Grøn 2006, 2007; Bilgrau 2006; Stær 2009). Alligevel har det været overraskende svært at finde tekster, som kobler kunstpædagogisk praksis med et solidt læringsteoretisk grundlag, hvorfor jeg i eksempel 1 har valgt at analysere en overvejende praksisorienteret tekst, mens jeg i eksempel 2 analyserer en overvejende teoretisk tekst.

\section{Eksempel 1: The Art Gallery HaNDBOOK: LEARNING IN GALLERIES}

Tate Publishings bog The Art Gallery Handbook (Charman et.al. 2006) har, som navnet antyder, en praksisorienteret tilgang med fă teoretiske referencer. Bogen er inddelt $\mathrm{i}$ to dele: Thinking about Galleries og Learning in Galleries. Sidstnævnte indeholder bl.a. kapitlerne Ways in to looking at Art, hvor den didaktiske tilgang forklares og begrundes og A Structured Approach, hvor et forslag til at undervisningsforløb, gennemgås trin for trin.

Teori: Bogens væsentligste didaktiske begreber er laring og fortolkning ("interpretation"), hvor særlig fortolkningsbegrebet forklares omhyggeligt. Bl.a. fremhæves viden om, og evne til, fortolkning af visuelle fænomener som en væsentlig kvalifikation $\mathrm{i}$ en nutidig verden: "For those pupils who do not continue their art practice beyond school, the creative and critical skills of interpretation are equally necessary as a tool to negotiate our world of visual complexity and richness" (ibid.: 54). Bogens læringssyn er erklæret konstruktivistisk, hvilket defineres som at den lærende skaber mening gennem at finde forbindelsespunkter mellem egene forforståelser, værdier og opfattelser og kunstværket i, hvad jeg vil definere som en hermeneutisk proces (ibid.: 57). 
Målsetning: Overordnet set drejer det kunstpædagogiske møde sig her om at lære forskellige måder at åbne et værk på med henblik på at gøre kunsten meningsfuld. Herudover nævnes det som væsentligt, at eleverne lærer at blive "en uafhængig museumsbesøgende" (ibid.: 80). Når det kommer til den foreslåede workshop er formuleringerne præget af en læringsterminologi rettet direkte mod skolens krav, hvor det overordnede mål bliver" ... to extend your pupils' learning whilst meeting the requirements of the national curriculum" (ibid.: 79), og ser man på modellens enkelte trin er målene klart orienteret mod at understøtte den effektive læring, fx i det første trin "orientation", hvor det pointeres at "When the pupils have an overview of the format and rationale of the session they become more committed and therefore effective learners" og i det sidste trin "Whole-group session/plenary": "[...] to ensure that pupils have understood their learning" (ibid.: 80, mine fremhævelser).

Forløb: I kapitel 7 præsenteres en 90-minutters "gallery workshop", som lærere selv kan gennemføre ved hjælp af den vedlagte Visit Planner. Workshoppen er struktureret med henblik på at guide eleverne fra umiddelbar respons på værkerne til stadig mere grundige analytiske tilgange (ibid.: 79). Den har fem trin og varer en og en halv time: 1) "orientation" (15 min.), 2) "a work in focus" (20 min.), 3) "additional activity/introduction to small-group work" (20 min.), 4) "working in small groups/reporting back" (20 min.), 5) "whole-group discussion/plenary" (15 min.) (Ibid.: 80). Som rammeværk for en fortolkende praksis på trin 2 og evt. på trin 4 og 5 præsenteres Ways In, fire tilgange til tolkningen af et værk. Denne starter med de enkelte deltageres personlige associationer for derefter at be- væge sig videre til objektet (værket som fysisk tilstedeværelse), indholdet (det, værket forestiller/handler om) og endelig konteksten (kunstneren, kulturen, samfundet osv.). Således orienteres eleverne mod kunstværkers forskellige betydningsniveauer og der skabes tæt forbindelse mellem elevernes erfaringer og kunstverdenens koder.

\section{EKSEMPEL 2: MENINGS- OG IDENTITETSSKA- BELSE I MODERNE KUNST}

Den amerikansk-norske forsker Palmyre Pierroux' afhandling Meaning, Learning and Art in Museums. A Situated Perspective (2006) indeholder dels en teoretisk og metodisk del, dels fire artikler, hvoraf et par stykker omhandler undersøgelser af kunstpædagogisk praksis. En af artiklerne (Pierroux 2005) diskuterer, hvilke typer af meningskonstruktion gymnasieelever skaber i dialogbaserede undervisningsforløb i skolen og på kunstmuseet. Jeg vil her se nærmere på Pierroux' beskrivelse og analyse af et undervisnings-segment på Philadelphia Art Museum, idet hun i særlig grad fremhæver dette eksempel som befordrende for elevernes individuelle og kollektive læring.

Teori: Pierroux udgår teoretisk fra sociokulturel læringsteori med særlig vægt på den russiske kulturhistoriske skole (L.S. Vygotsky, A. Luria og A. Leont'ev) samt J. Wertsch' udvidede version af dette projekt (Pierroux 2006: 713). Hun betragter læring som en meningsskabende aktivitet integreret i specifikke sociale praktikker, og anvender derfor empiriske studier af kunstpædagogisk praksis som udgangspunkt for analyser af relationen mellem ytring og mening $\mathrm{i}$ et dialogisk perspektiv (ibid.: 17-18). Selvom Pierroux understreger læringens sociale dimension anvender hun elevernes identitetskontruktion som en af de 
38 væsentligste analytiske markører for vellykkede læreprocesser. Centrale analysebegreber er her "mastery", som betegner" ... student activity concerned with knowing how to use the social language of art history and art theory as cultural tools" og "appropriation", som henviser til "[aktiviteter hvor] ... specific narratives as cultural tools, [...] become more identity than knowledge resources, 'a means for anchoring and constructing one's sense of who one is"” (ibid.: 18, mine fremhævelser). ${ }^{8}$

Forløb: Det undervisnings-segment, Pierroux analyserer, er fra en dialogbaseret omvisning om moderne kunst og samtidskunst på Philadelphia Art Museum med en amerikansk gymnasieklasse. Efter at klassen har været i tre forskellige sale, når de til salen med Duchamps værker deriblandt det berømte værk Fountain. Herfra gengives og analyseres en dialog mellem formidleren og flere elever om, hvordan man kan definere, om noget er kunst.

Målsatning: Målet med forløbet er som udgangspunkt kunstfagligt orienteret, nemlig at give eleverne forståelse for ord og begreber i moderne kunst. I segmentet fokuserer dialogen mellem formidler og elever på selve kunstbegrebet. Ved hjælp af sine to analysebegreber introducerer Pierroux imidlertid en dobbelt målsætning: den gode dialog skal ideelt set ikke blot føre til at eleverne tilegner sig viden om moderne kunstbegreber, men til at denne viden integreres som en del af elevernes identitet. Med henblik på at vise, hvorledes dette kan foregå, fremhæver Pierroux særlig en dialog mellem formidleren og eleven "Jack" om, hvem der egentlig har definitionsretten til "kunst", og hun konkluderer: "Through a joint social activity of constructing meaning, art for this student becomes something other than mastering concepts in aesthetics or art history; Jack's appropriated view on art seems to be more about a process of crafting identity". (Pierroux 2005:84).

\section{DISKUSSION}

I en didaktisk optik ligger fokus i de to tekster på den eller de lærendes tilegnelsesprocesser i forhold til det at skabe mening. Meningen skal imidlertid først og fremmest findes i forhold til museets egne omdrejningspunkter: kunstværket, kunstbegrebet og museumsbesøget, og kun $\mathrm{i}$ en indledende fase inddrager forløbene elevernes personlige interesser og associationer. Den personlige relation skal give eleverne en erfaring af, at kunsten giver mening for dem og at det giver mening at lære om kunst. I sidste ende er det elevernes identitet som "kunstkyndige" eller måske endda "kunstelskere" der står på spil. Det er altså ikke nok at vide noget om kunst (i Pierrroux' terminologi at "mestre" kunstforståelse som kulturelt værktøj) eleverne skal "appropriere" denne viden som en integreret del af deres personlighed.

I denne konception er lærerens/formidlerens rolle først og fremmest at optræde som facilitatorer for elevernes individuelle og kollektive meningskonstruktion i mødet med værkerne, udstillingen og museet. Hvor den æstetiske oplevelse var baseret på kunstværket som "magisk", er det her elevernes indre og skjulte læringspotentialer, der er "magiske", og teksterne beskæftiger sig med, hvordan disse kan stimuleres og synliggøres med henblik på at optimere de ønskede resultater.

I forhold til de indledende modeller mener jeg, at eksemplerne på denne konception, trods brugen af et sociokulturelt læringsbegreb, i sidste ende fokuserer mere på individets læring end på kollektive mål, samt at læ- 
ringsmålene omhandler læring som erkendelse og meningsskabelse i forhold til allerede eksisterende forståelser af kunst, snarere end som overskridelse af disse.

\section{TREDJE KONCEPTION: KUNSTPADAGOGIK BASERET PÅ TEORIER OM DIDAKTIK OG DANNELSE}

På samme måde som "didaktik" er "dannelse" et så godt som ukendt begreb i engelsksprogede curriculum-tekster, og i Eisner og Vallances tekst er det nærmeste, man kommer en dannelsesbegrebet, en konception kaldet Curriculum as Academic Rationalism. Her er der tale om en diciplinorienteret tilgang baseret på en klassisk humanistisk dannelsestænkning, hvor dannelse primært drejer sig om kendskab til kulturarven (Eisner og Vallance 1974: 12-13).

I Skandinavien og Tyskland derimod er der tradition for at tænke dannelse bredere som den type af relation, der gennem forskellige typer af læreprocesser udvikles mellem menneskets forhold til sig selv, til verden og til samfundet (Slagstad et al. 2003: 9-12). Det betyder, at samfundets og det enkelte menneskes udvikling og læring ses som tæt forbundne, og at undervisning altid må være bevidst om forholdet mellem den enkelte elev, undervisningssituationen i sin helhed og de institutionelle, kulturelle og samfundsmæssige faktorer, der indgår som en del af undervisningssituationen. Begreberne dannelse og didaktik er indbyrdes afhængige, idet det samlet set drejer sig om, hvordan vi tilrettelægger og praktiserer uddannelse til mennesker som aktive, kritiske og selvstændige deltagere i samfundets nutidige og fremtidige fællesskaber.

Kunstpædagogik baseret på teorier om didaktik og dannelse er optaget af, hvorledes mødet med kunst kan bidrage til at give ele- ven redskaber og tankeformer som gør hende eller ham i stand til at møde virkeligheden (og kunsten som en del af denne) på en måde, som på den ene side er selvstændig og fri, men på den anden side står i relation "..til et kulturelt, socialt og eller politisk fællesskab og til menneskeheden i sin helhed" (ibid.: 11). Dette paradoks løses som oftest gennem tydelighed mht. relationen mellem fællesskabets værdier og den enkeltes holdninger. Bl.a. foreslår Mie Buhl med udgangspunkt i Wolfgang Klafkis kategoriale dannelsesteori at læreren foreslår noget "...jeg af de og de grunde mener er god kunst", som eleven derefter selvstændigt kan bruge til at "modellere sig med" (Buhl 2000: 166-167), mens Mette Houlberg Rung med afsæt i Lars Henrik Smidt introducerer begrebet "selvdannelse" og foreslår, at kunstmuseet ses som en "platform", der står til rådighed for de besøgendes individuelle lærings-konstruktioner (Rung 2008).

Jeg har valgt at se nærmere på to nordiske tekster, der primært fokuserer på didaktik, men som implicerer et dannelsesbegreb, der ligger tæt op ad den kategoriale og konstruktivistisk orienterede dannelsesforståelse man finder hos Buhl og Rung.

\section{EKSEMPEL 1: RELATIONEL-PLURALISTISK KUNSTDIDAKTIK}

I artiklen Formidling af bilder til barn - som kunstdidaktisk diskurs (2006) introducerer den norske forsker Venke Aure begrebet "kunstdidaktisk diskurs" og begrebet anvendes igen i bogen Konsten som läranderesurs (Aure et.al. 2009), hvor kunstpædagogikken ved Nasjonalmuseet i Oslo analyseres. I artiklen defineres kunstdidaktik som: ”De kunstrelaterte og didaktiske fenomenene, som indgår i formidlingssammenheng" (Aure 2006: 135) og "uli- 
HELENE ILLERIS

40 ke ideologier og praksiser knyttet til kunstutstillingsvirksomhet" (ibid.: note 6).

Teori: Artiklen fremanalyserer tre traditionelle typer af kunstdidaktik: "formalæstetisk", "dannelsesteoretisk" og "dialogforankret". Disse betegnes som bærere af lukkede og essentialistiske kunstdidaktiske koder (ibid.:141). I forlængelse heraf foreslås en fjerde, som tager højde for kendetegnene ved nutidig kunst: "relationel-pluralistisk kunstdidaktik". Teoretisk anvender Aure en relationel og dynamisk didaktisk tænkning, som den er kendt fra Bjørndal og Liebergs (1978) didaktiske relationsmodel. Modellens gensidige sammenhæng mellem formidlingsfaktorene er, siger Aure, i overensstemmelse med samtidskunstens åbne og kommunikative aspekt, hvor "værket" ikke længere kan forstås som et autonomt objekt, men snarere som en begivenhed, der konstitueres $\mathrm{i}$ interaktion med beskueren. Hermed åbnes der for, hvad Bahktin har kaldt "dialogiske relationer" mellem værk, elev og formidler baseret på "åbne koder" (ibid.: 142-145).

Målsatning: Målet med den relationel-pluralistiske kunstdidaktik er at øge elevernes "fortrolige blik" i mødet med kunst, ikke mindst samtidskunst. Fortroligheden skal imidlertid ikke begrænses til mødet med kunstværkerne, den skal være af en åben og nysgerrig karakter, således at eleverne opnår en åben erfaring, som umiddelbart kan knyttes til "virkelighedsfortællingerne" uden for kunstens rum: "Denne kunstdidaktiske tilnærmingen tilstreber å forankre kunsten i samtidens virkelighetsfortellinger, og i motsetning til en lukket kunstforståelse knyttet til selve bildet er idealet et verk, som åpner sig for ulike omgivelser, situasjoner og tolkninger" (ibid.: 142).

Forløb: De væsentligste midler i en relationel-pluralistisk kunstdidaktik er didaktisk re- fleksion, brug af interaktive strategier og tydeligt personligt engagement fra lærere og formidlere (ibid.: 147). Aure giver ganske kort et eksempel på relationsorienteret kunstdidaktiksk praksis i sin analyse af kunstpædagogik ved Nasjonalmuseet i Oslo. Det drejer sig om observation af en omvisning i samtidskunstudstillingen Fantastisk Politikk. Kunst $i$ turbulente tider (2006-2007), hvor én af omviserne, efter at have gennemgået fire af udstillingens værker deler eleverne op i grupper på fire og giver dem som opgave at præsentere et selvvalgt værk på udstillingen for de andre, og dermed påtage sig rollen som "lærere". I den efterfølgende dialog kommer en række spontane forståelser af værket i spil, hvilket bl.a. får formidleren til at udtale at "Kunsten diskuterer med oss, den inviterer til mange tolkninger" (Aure et al. 2009: 173).

\section{Eksempel 2: Performativ kunstPedago- GIK}

I 2003 publicerede jeg artiklen Performative positioner $i$ kunstpadagogik i det lille svenske tidsskrift Valör (Illeris 2003). ${ }^{9}$ Denne indeholder bl.a. en model for det kunstpædagogiske møde, som siden, trods sin enkelhed og i forskellige variationer, har fungeret som et afsæt for min egen didaktiske tænkning på det kunstpædagogiske område. Teksten indeholder enkelte mindre praksiseksempler, men jeg har valgt i stedet at inddrage et forløb af nyere dato, nemlig det eksperimenterende forløb "Kunststafetten" på Arken som jeg i 2008 deltog i som observatør, og som jeg har beskrevet i artiklen Skibet er lastet med ... samtidskunst (Illeris 2008a).

Teori: Modellen over mødet er, på samme måde som Bjørndal og Liebergs, en dynamisk, didaktisk relationsmodel, men til forskel fra 
andre lignende ( $\mathrm{fx}$ Samuelsen 2003) skelner den ikke mellem hovedfaktorer og rammefaktorer, men udgår fra fem ligeværdige positione som alle, om end i forskellig grad, bidrager til iscenesættelsen af kunstpædagogiske møder: performerpositionen, omgivelsepositionen, temapositionen, objektpositionen og publikumpositionen. Pointen er, at mens performerpositionen i det traditionelle "kunstpædagogiske ritual" næsten udelukkende indtages af formidleren, mens eleverne reduceres til publikum (dem performeren taler til), værkerne til objekter (det performeren taler om), udstillingen til tema (sammenbinding), museet til (uvedkommende/forstyrrende) omgivelse, så kan man i stedet arbejde didaktisk med at aktivere flere positioner som performere. Således kan $\mathrm{fx}_{\mathrm{x}}$ museet, med inspiration fra Carol Duncan (1995), betragtes som en væsentlig performer, idet det iscenesætter såvel publikum som formidler, værker og udstillinger i bestemte rammer, såvel arkitektoniske som diskursive. Ligeledes kan man i mødet vælge i højere grad at fokusere på værkernes performance, og hvorledes de iscenesætter relationen til publikum på en bestemt måde osv.

Målsetning: Artiklen opererer med en målsætning, som ligger ganske tæt på Aures: "I stedet for at søge at tvinge eleverne til at acceptere museumsrundgangens og skoletimens ritualer, er en aktuel rolle for kunstpædagogikken i senmoderne samfund at vise, hvordan man kan interagere med kunst på forskellige måder" (Illeris 2003: 27). I praksiseksemplet "Kunststafetten" er målsætningen at stimulere "visuel refleksivitet", dvs. at eleverne skulle blive opmærksomme "... ikke alene på hvad de ser, men på hvordan de ser, og at man ser forskelligt alt efter hvem man er, og hvilken situation, man befinder sig i” (Illeris 2008a: 27). Det langsigtede mål er, at eleverne lærer at forholde sig til deres eget blik, og det præciseres at "I samtidens komplekse samfund kan kunstværker, lige så lidt som alle de andre visuelle fænomener, tages for givet som kilder til bestemte former for oplevelse..." (ibid.: 29).

Forløb: Kunststafetten var opdelt i fem delforløb, tre på skolen og to på museet. Jeg vil her omtale de to delforløb på museet, som tog udgangspunkt i hhv. museet som performativ position og værket som performativ position. Ved det første besøg blev museets performance som institution, som arkitektur og som rum studeret gennem den didaktiske iscenesættelse af forskellige typer af relationer, $\mathrm{fx}$ at gå to gange igennem "den røde gang" og reflektere først over den personlige oplevelse af gangen og derefter en kollektiv oplevelse ud fra et fælles fokus. Det andet besøg på Arken tog udgangspunkt i udvalgte værker, som ligeledes fik mulighed for at performe forskelligt, bl.a. ved at eleverne havde lavet briller af pap, så de kunne prøve i fællesskab at "se" et værk forskelligt alt efter om de havde brillerne på, eller om de tog dem af.

\section{DISKUSSION}

Som det er kommet til udtryk i de præsenterede tekster, fokuserer kunstpædagogik baseret på teorier om didaktik og dannelse, meget på at skabe en forbindelse mellem mødet med kunsten og en bredere vifte af kompetencer, som relaterer til en kompleks senmoderne virkelighed. Samtidskunsten kommer her i fokus, fordi den siges at operere med samme relationelt orienterede kommunikationsformer som de, der kunne være relevante i en senmoderne dannelsesoptik. Didaktisk fremhæves åbne dialogformer, en kombination af sanselige og refleksive tilgange, samt leg med rolleskift og positionering. 
Et spørgsmål, der rejser sig, er imidlertid hvorvidt sådanne åbne didaktiske former er i stand til at tilgodese alle elevers behov, eller om de alene tilgodeser de i forvejen velreflekterede, og måske endda kunstvante, elever, som er kompetente navigatører i komplekse virkeligheder. Netop fordi denne konception jfr. de indledende modeller, overvejende fokuserer på et kollektivt udbytte af mødet med kunsten gennem skabelsen af fælles fortællinger, kan den risikere ikke at opfange og reflektere den enkelte elevs læreprocesser, ligesom eksemplerne fokus på åben og nysgerrig fortrolighed og visuel refleksivitet kan komme til at bære præg af en "indforståethed" i forhold til samtidskunstens og formidlingens implicitte koder.

\section{FJERDE KONCEPTION: KUNSTPEDAGOGIK BASERET PÅ TEORIER OM SOCIAL KRITIK OG FORANDRING}

With this orientation there is a strong emphasis on the role of education and curriculum content within the larger social context. Social reconstructionists typically stress larger societal needs over individual needs; the overall goals of education are dealt with in terms of total experience, rather than using the immediate processes which they imply. Social reform and responsibility to the future of society are primary. (Om Social reconstruction-relevance, Eisner and Vallance 1974:10)

Trods sine rødder i kritisk pædagogik tilbage fra 1930 'erne og ikke mindst 1970 'erne, er denne konception forholdsvis ny på det kunst- og museumspædagogiske felt, hvor begreber som multikulturel pædagogik, medborgerskab, social inklusion og social bæredygtighed begyndte at dukke op i 1990'erne, og først for alvor er blevet aktualiseret inden for skandinavisk kunstpædagogisk praksis i løbet af de sidste 5-10 år. I Storbritannien er museologisk og museumspædagogisk forskning i "social inclusion" helt central, og der er udarbejdet flere større rapporter og andre publikationer på området (fx GLLAM 2000; DCMS 2000; Dodd og Sandell 2001). I Skandinavien er antallet af publikationer langt færre, men nogle stykker af de, som findes, interesserer sig, i modsætning til de britiske tekster, specifikt for social inklusion på kunstmuseer (fx Laigaard 2005; Illeris 2008b; Aure et al. 2009).

Kunstpædagogik baseret på teorier om social kritik og forandring tager udgangspunkt i et opgør med kunstmuseets traditionelle rolle som et elitært og ekskluderende rum for i stedet at arbejde med inkluderende praksisser særligt målrettet udsatte sociale grupper, for hvem kunst og museer sjældent opleves som "deres sted”. Den didaktiske målsætning er således, ved hjælp af en tydelig overskridelse både af elevernes og af kunstmuseets traditionelle roller, at skabe nye og anderledes mødesteder, hvor såvel elever som museum kan konstruere og anvende inkluderende forståelser af hinanden. Viv Golding anvender $\mathrm{fx}$ begrebet "Museum Clearing" som metafor for et sådant "sted" (både i egentlig og i overført forstand) hvor en "sammensmeltning af horisonter", omend midlertidigt, kan realiseres (Golding 2005). Også det britiske kulturministerium understreger at social inklusion sætter andet og mere på spil end målgruppeudvikling og tilgængelighed: det drejer sig om museet som en aktiv faktor $i$ sociale forandringsprocesser (Illeris 2008b: 10).

Måske fordi området er forholdsvis nyt, er der fortsat mangel på kunstpædagogiske tekster som kobler didaktisk teori og praksis i en social forandringsoptik, men jeg har valgt to overvejende teoretiske tekster (hvoraf den ene 
er min egen), som i det mindste skitserer mulige praksiseksempler.

\section{EKSEMPEL 1: NKISI: THE POWER PROJECT}

Den britiske museumsforsker Viv Golding har længe undersøgt forskellige modeller for social inklusion på kunst- og kulturhistoriske museer bl.a. i samarbejde med Horniman museet i den sydlige del af London. I kapitlet $\mathrm{Le}$ arning at the Museum Frontiers. Democracy, Identity and Difference (Golding 2007), diskuterer hun tre case studier, fra et større forskningssamarbejde mellem Horniman Museum Educational Department, Goldsmidts College og et team på 25 lokale lærere og deres elever, hvoraf mange er socialt udsatte og flere kæmper med indlæringsvanskeligheder. Et af de tre studier, "Nkisi-projektet", involverede lærere og elever fra Kemnell Technical College og fandt sted dels på skolen, dels i museets permanente kunst- og kulturudstilling African Worlds.

Teori: Golding har sit teoretiske udgangspunkt $\mathrm{i}$ en feministisk-hermeneutisk tradition, som forsøger at møde stereotype opdelinger mellem "dem" og "os" gennem oparbejdningen af en fælles humanistisk forståelse, der ikke udvisker eller ignorerer forskellighed (Golding 2005: 51). I Frontiers-projektet uddybes denne tradition gennem studier af "Black theoretical perspectives", hvorfra hun bl.a. citerer Audre Lorde: ${ }^{10}$ "Within the interdependence of mutual (non-dominant) differences lies that security which enables us to descend into the chaos of knowledge and return with truer visions of our future, along with the concomitant power to effect those changes which can bring that future into being" (citeret fra Golding 2007: 315, Goldings fremhævelser).

Målsatning: Frontiers-projektets overordne- de mål var "...to promote learning that involves recognition of complex layering of ideas: Difference and similarity, between and within communities, at a local and a global level" (ibid.). Nkisi-projektet, også kaldet "the power project” tog udgangspunkt i Horniman museets samling af "minkisi" (flertal af nkisi) som er magt/kraft-figurer ("power figures") lavet af ritual-eksperter fra Kongo-folket. Målet med projektet var, at overskride etablerede magtstrukturer gennem at arbejde ikke-hierarkisk i et multiracialt team (ibid.: 318). En særlig udfordring var at involvere de overvejende hvide, men socialt udsatte, elever og bringe dem i kontakt med Londons multikulturelle virkelighed. I en kunstpædagogisk optik var det desuden en pointe med projektet at det klassiske vestlige kunstbegreb blev udfordret gennem at inddrage objekter, der traditionelt set klassificeres som "kultur" i stedet for "kunst".

Forløb: Projektet varede i alt otte uger og startede med en introdag på skolen, som inkluderede en workshop med objekter fra Afrika - diskussion, refleksion, dans, drama og kreativ skrivning efterfulgt af en anden workshop under ledelse af en kunstner, hvor drengene bl.a. lærte silketryk og udformede deres første banner ud fra power-temaet. (ibid.: 319). Herefter fulgte et besøg på museet med et oplæg fra Golding om minkisi-samlingen i relation til magt $/ \mathrm{kraft}$. Dette affødte et større arbejde med dekonstruktion af begrebet "fetich" og de fordomme, der knytter sig til dette set $\mathrm{i}$ et eurocentrisk, historisk perspektiv. Ud fra samlingen arbejdede drengene med at skrive "acroistic poems" først i par og siden i grupper, et arbejde der fortsatte på skolen gennem undersøgelser af forskellige typer af personlige digte der kunne relateres til nkisi-figurernes kraft. Som afslutning på projektet skabte ele- 
HELENE ILLERIS

44 verne en "power-book" med deres digte og de lavede tableaux vivant over deres nye nkisi-inspirerede forståelser af begrebet "power". Goldings konklusion på projektet er at "During the collaborative project notions of failure and inadequacy were interrogated, destabilised and reconstructed in new alliances that redefined the terms 'self' and 'other', and demonstrated that in a twenty-first century world of suspicion and misunderstanding, museums can provide a new space of coherence, relevance and meaning for democratic society" (ibid.:328).

\section{EKSEMPEL 2: SPEAK UP}

Som det andet eksempel på denne kunstpædagogiske konception vil jeg bruge workshoppen "Speak Up", der fandt sted på Arken i 2007, og som jeg har beskrevet i artiklen Visual events and the friendly eye: modes of educating vision in new educational settings in Danish art galleries (Illeris 2009). Workshoppen blev gennemført med en række skoleklasser i forbindelse med Duane Hanson-udstillingen The American Dream ${ }^{11}$ og havde som mål at engagere eleverne i interaktive udvekslinger med Hansons skulpturer gennem at give dem "stemmer".

Teori: Artiklens teoretiske udgangspunkt er visuel kultur-studier og her særlig den hollandske forsker Mieke Bals studier af de magtforhold, kunstmuseet etablerer og "naturaliserer" mellem museet/formidleren som den autoritet (1. person) som iscenesætter beskueren og kunstværket i rollen som hhv. den som bliver talt til (2. person) og den som bliver talt om (3. person) (Bal 1996). Som alternativ til traditionel modernistisk formidlings mere eller mindre ukritiske reproduktion af dette forhold, analyseres eksempler på kunstpædagogik som dynamiske "visuelle begivenheder", hvor magtforholdet problematiseres og såvel elever som kunstværker får stillet alternative positioner til rådighed med henblik på at anvende hvad Bal med filosoffen Lorraine Code karakteriserer som et "venskabeligt blik".

Forløb: Speak Up-workshoppene varede fire lektioner (3 klokketimer) og bestod af følgende segmenter: 1) kort introduktion til udstillingen, gennem brug af forskellige "blik", hvor eleverne selv fik mulighed for at vælge et mindre antal skulpturer, de ønskede at relatere særligt til. 2) I mindre grupper skulle eleverne "give stemmer" til en eller flere valgte skulpturer gennem brug af en digital diktafon. 3) Grupperne redigerede deres lydfiler på computer. 4) Afspilning af skulpturernes "fortællinger" for de øvrige elever ude i udstillingen. 5) Fælles diskussion af forløbet og dettes læringspotentiale (metarefleksion). 6) Uploading af lydfilerne på Arkens blog.

Målsatning: Artiklen omtaler først museets mål med undervisningen: at stimulere elevernes bevidsthed om anvendelsen af forskellige blik på kunstværker, at skabe kollektive fortællinger i udstillingen, samt at arbejde med metarefleksiv praksis (Illeris 2009: 24). Gennem analyser af faktiske forløb i en social forandrings-optik diskuterer artiklen endvidere, hvordan Speak $U_{p}$ kan ses som eksempel på brug af ikke-objektificerende og ikke-subjektificerende synspraktikker (ibid.: 28), fx når en gruppe 15-16 årige drenge giver stemme til skulpturen Derelict Woman som forestiller en forslået og bevidstløs (død?) kvinde, der ligger på gulvet, og dermed stiller spørgsmålstegn ved udstillingens implicitte magtrelationer gennem anvendelsen af et "dialogisk blik".

\section{DISKUSSION}

De to eksempler ser kunstpædagogikkens for- 
mål som værende en overskridelse af etablerede magtrelationer på kunstmuseet og i samfundet med henblik på at skabe frigørende muligheder for nye og anderledes kollektive og individuelle positioneringer. De kan således placeres som værende overvejende kollektivt orienterede og rettet mod læring som overskridelse.

De eksemplificerede forløb er karakteriseret ved at være længere end "normale" omvisninger, og ved at eleverne ender op med et eller flere egne produkter, som de viser frem for hinanden og evt. for en større offentlighed. På samme måde som i det tidligere omtalte $4 a-$ mellem musik og billedkunst, fusioneres elevernes og museets/værkernes perspektiver i et tredje produkt, evt. i et samarbejde mellem skole og museum. Hermed udnyttes en oplagt mulighed for at øge elevernes oplevelse af "ejerskab" til kunstoplevelsen.

I projekterne arbejdes på et aktionistisk og eksperimenterende grundlag med at udvikle "alternative rum" for kunstpædagogisk praksis. Hermed ligger eksemplerne i forlængelse af 1970 'ernes kritiske og frigørende pædagogik, og der er da også, og måske særligt i Nkisi-projektet, en hvis risiko for at havne i nogle af de samme "faldgrupper", hvad angår en normativ, næsten formynderisk, holdning til hvorledes social udsatte gruppers "behov" og "interesser" defineres. Hvis man ikke er konstant reflekterende over for, hvilke midler man bruger i en sådan kunstpædagogisk praksis, risikerer man med andre ord at erstatte gamle magtrelationer med nye - når blot dette sker i "den gode sags tjeneste". Brugen af feministisk og poststrukturalistisk inspireret tænkning, som fremhæver retten til forskellighed og demokrati, burde dog på længere sigt give mulighed for at udvikle længerevarende dynamiske kunstpædagogiske relationer, som i mod- sætning til de øvrige konceptioner har et mere radikalt potentiale, når det gælder overskridelse og nytænkning af kunstmuseet som pædagogisk og didaktisk institution og kunstværkets og beskuernes roller i forhold hertil.

\section{AfsLUtNING}

Ved at undersøge fire kunstpædagogiske konceptioner og ved at anvende disse til at analysere en række aktuelle kunstpædagogiske tekster håber jeg at have givet en, efter min opfattelse tiltrængt, indsigt $\mathrm{i}$, de didaktiske diskurser som p.t. opererer i det kunstpædagogiske felt. Selvom mange kunstmuseer efterhånden arbejder med at formulere og implementere præcise didaktiske målsætninger, kan jeg, ud fra mit mangeårige engagement som forsker i feltet, fortsat overraskes over, at didaktisk refleksion i mange tilfælde synes at komme i anden række i forhold til tilgange, som forholdsvis ureflekteret orienterer sig mod enten den umiddelbare oplevelse (det skal være "sjovt", "spændende" eller "anderledes") eller opfyldelse af skolernes (særligt gymnasiernes) efterspørgsel efter nøje afgrænset kunstfagligt indhold. I stedet burde det være naturligt, at museerne, på samme måde som skolerne, arbejder med at udvikle relevante didaktiske praktikker, som står i et reflekteret og begrundet forhold til den type relation, man ønsker at eleverne skal udvikle til kunsten, til museet og til undervisningen. Det er ikke nok at have som formål at "det skal være sjovt at gå på museum", og at eleverne helst skal "komme tilbage", man må også vide, hvorfor og hvordan man ønsker, at eleverne skal bruge museet og kunsten fremover, samt hvilke elever (og lærere) man faktisk henvender sig til. Reflekterer man ikke over det, reproducerer man så at sige "automatisk" de stereotyper, eleverne allerede 
46 kommer med, $\mathrm{fx}$ at kunstpædagogik (læs: formidlerens performance) kan være mere eller mindre underholdende, at kunstens koder ligger i værkerne og ikke i relationen, at man ikke kan stille spørgsmålstegn ved museets autoritet, og at kunst og kunstmuseer først og fremmest er for veluddannede, hvide, danske kvinder (som regel direkte repræsenteret ved omviseren).

De otte eksempler giver meget forskellige bud på, hvorledes kunstpædagogisk teori og praksis kan reflekteres didaktisk, men fælles for dem alle er, at de vil eleverne noget, og at de forsøger at tydeliggøre, hvad dette "noget" består i. Forskelligheden illustrerer, at der ikke findes noget endegyldigt svar på kunstpædagogikkens formål og metode, men at der, trods alt, findes flere rimeligt veludviklede teorier og eksempler på praksisforløb, og at en del af disse faktisk er at hente i aktuel skandinavisk litteratur.

\section{NOTER}

1. Artiklen er resultat af en undersøgelsen Konceptualisering af grundforskningsprojekt $i$ kunstformidlingsdidaktik støttet af Novo Nordisk Fonden

2. De fem konceptioner er: Self-Actualization or Curriculum as Consummatory Experience; Curriculum as the Development of Cognitive Processes; Curriculum as Academic Rationalism; Curriculum for Social Reconstruction-Relevance og endelig Curriculum as Technology (Eisner og Vallance 1974: 1-19)

3. "Læreplaner" er her en oversættelse af det engelske curricula (flertalsform af curriculum), da jeg mener at Goodlad her anvender denne snævre betydelse af ordet.

4. Egen oversættelse af Goodlads betegnelser: Ideological Curricula, Formal Curricula, Perceived
Curricula, Operational Curricula and Experiential Curricula (Goodlad 1979: 60 ff.)

5. I forskningsprojektet Kunsten som laringsresurse brugte Venke Aure, Hans Örtegren og jeg Goodlads fem "læseplaner" i udviklingen af en operationaliserbar metode for empirisk didaktisk forskning ift. dataindsamling: her valgte vi at tale om fem "niveauer": det ideologiske, det formaliserede, det perciperede, det operationaliserede og det erfarede (Aure et al. 2009). Denne tilgang var envidere inspireret af Venke Aure og Jarleiv Hauges brug af samme Goodlad-inspirerede begreber i rapporten Pilotgallerier for barn og unge. Kunstformidling på tvers (Aure og Hauge 1996).

6. Igen med inspiration fra Pierre Bourdieus feltteori (fx Bourdieu 1993) definerer jeg "kunstpædagogik" som et (forholdsvis nyt og skrøbeligt) praksisfelt, som omfatter dels den pædagogiske praksis, der ved hjælp af undervisning, vejledning, workshops eller andre læringsorienterede iscenesættelser har til formål at skabe møder mellem elever og kunstens verden/værker, dels den videnskabelige praksis at undersøge og/eller komme med forslag til nye forståelser og/eller udvikling af denne praksis. Hermed angiver "kunstpædagogik" et komplekst felt af sociale relationer, som omfatter møder mellem en række "positioner", herunder elever, undervisere, værker, omgivelser og temaer (Illeris 2003). Tilgrænsende og delvis overlappende betegnelser er på den ene side "kunstformidling", som anvendes om kunstpædagogik i museumsregí, og på den anden side "kunstdidaktik", et forholdsvis nyt begreb som i min forståelse fokuserer mere snævert på undervisningsforløb (for en bredere forståelse se Aure 2006). Selvom denne artikel primært omhandler kunstpædagogik på museer, anvender jeg ikke begrebet "kunstformidling", fordi ordet "formidling" i min pædagogiske optik konnoterer en oppe fra og ned iscenesættelse af deltagerne (nogen formidler noget på forhånd givet til nogen andre). 
7. På kunstens område i Danmark måske mest markant på Esbjerg Kunstmuseum, hvor man i en årrække har samarbejdet med kunstpsykologen Bjarne Sode Funch (se fx Funch et al. 2009).

8. Citatet i citatet er fra Wertsch 2002: 120

9. En redigeret version af denne tekst er publiceret $\mathrm{i}$ J. Krejsler, N. Kryger \& J. Milner (red.), Pædagogisk antropologi. Et fag i tilblivelse, s. 119-136 (Illeris 2004)

10. Audre Lorde (1934-1992) var en carraibisk-amerikansk forfatter, digter og aktivist - $\mathrm{i}$ egne ord "black, lesbian, mother, warrior, poet" (http://en.wikipedia.org/wiki/Audre_Lorde)

11. Duane Hanson (1925-1996) var en amerikansk socialkritisk kunstner, der i 1960'erne, blev kendt for at udføre sine glasfiberskulpturer efter levende model i nøjagtige 1:1 afstøbninger. Han arbejdede efter støbeprocessen videre med dem, malede dem og forsynede dem med rekvisitter, som karakteriserede deres miljø, status, erhverv og skæbne (http://da.wikipedia.org/wiki/Duane_Hanson)

\section{Referencer}

Adams, Marianna; Falk, John H.; Dierking, Lynn D.: Things change. Museums, Learning and Research. Xanthoudaki, Maria; Tickle, Les; Sekules, Veronica (eds.): Researching Visual Arts Education in Museums and Galleries. An International Reader. Kluwer Academic Publishers: Dordrecht 2003

Aure, Venke: Formidling av bilder til barn - som kunstdidaktisk diskurs. Tidsskrift for Børne-og Ungdomskultur Nr. 51, 2006: 133-153

Aure, Venke; Illeris, Helene; Örtegren, Hans: Konsten som läranderesurs. Syn på lärande, pedagogiska strategier och social inklusion på nordiska konstmuseer. Nordiska Akvarellmuseet: Skärhamn 2009

Aure, Venke og Hauge, Jarleiv: Pilotgallerier for barn og unge: Kunstformidling på tvers. Rapport RF-
Bilgrau, Julie: Det' for børn! Kunstformidling som barndomskonstruktion. En analyse af formidlingsmateriale fra tre danske kunstmuseer, samt argumentation for en tvardiscipliner tilgang til kunstformidling for børn. Upubliceret speciale. Afdeling for Kunsthistorie, Institut for Æstetiske Fag, Aarhus Universitet: Århus 2006.

Bal, Mieke: Double Exposures: The Subject of Cultural Analysis. Routledge: London 1996

Bjørndal, Bjarne og Lieberg, Sigmund: Nye veier $i$ didaktikken. Aschehoug: Oslo 1978

Bourdieu, Pierre: The Field of Cultural Production. Essays on Art and Literature. Polity Press: Cambridge 1993.

Buhl, Mie: Samtidskunstens pædagogiske udfordringer til billedkunstfaget i læreruddannelsen. Arvedsen, Karsten og Illeris, Helene (red.): Samtidskunst og undervisning - en antologi. Danmarks Pædagogiske Universitet: København 2000

DCMS (Department for Culture, Media and Sport): Centres for Social Change: Museums, Galleries and Archives for All. London 2000. http://www.culture.gov.uk/images/publications/centers_social_ change.pdf

Dodd, Jocelyn og Sandell, Richard: Including Museums. Perspectives on museums, galleries and social inclusion. RCMG: Leicester 2001

Duncan, Carol: Civilizing Rituals - inside public art museums. Routledge: London 1995

Eisner, Elliot W. and Vallance, Elizabeth (Eds.): Conflicting Conceptions of Curriculum. McCutchan: Berkeley: 1974

Funch, Bjarne Sode: The Psychology of Art Appreciation. Museum Tusculanum Press: København 1997

Funch, Bjarne Sode; Krøyer L.L.; Roald, T.; Wildt, E.; Ørum, B.: Børn i nærkontakt med kunst. Billedpedagogisk Tidsskrift. Nr. 3, 2009: 4-10

GLLAM (Group for Large Local Authority Mu- 
seums): Museums and Social Inclusion. The GLLAM Report. 2000

Goodlad, John I. and Associates: Curriculum Inquiry. The Study of Curriculum Practice. McGraw-Hill: New York 1979.

Golding, Viv: The Museum Clearing: A Metaphor for New Museum Practice. Atkinson Dennis and Dash, Paul (eds.): Social and Critical Practice in Art Education, Trentham Books: Staffordshire 2005: 51-66

Golding, Viv: Learning at the Museum Frontiers: Democracy, Identity and Difference. Knell, S. MacLeod, S. and Watson, S. (eds.) Museum Revolutions. Routledge, London 2007: 315-329

Grøn, Karen: Kurator for en dag - en leg i museets rituelle rum. Nordisk Museologi. Nr. 1, 2006: 4358

Grøn, Karen: Undersøgende, hyggere, scannere ogkultiverede. En undersøgelse af gæsters oplevelser og oplevelsesstrategier på Trapholt. Nordisk Museologi. Nr. 2, 2007: 46-61

Hein, George E.: Learning in the Museum. Routledge: London 1998

Hooper-Greenhill, Eilean: Museum and Galley Education. Leicester University Press: Leicester 1991.

Illeris, Helene: Performative positioner i kunstpædagogik. Valör. Konstvetenskapliga studier. Nr. 4, 2003: $15-28$

Illeris, Helene: Det pædagogiske forhold som performance: Ritualer og performative positioner i formidling af kunst på museer. I: J. Krejsler, N. Kryger \& J. Milner (red.), Padagogisk antropologi. Et fag i tilblivelse Danmarks Pædagogiske Universitets Forlag: København 2004, 119-136

Illeris, Helene: Kunstpadagogisk forskning og formidling I Norden 1985-2004. Nordisk Akvarelmuseum. Skärhamn: 2005

Illeris, Helene: Skibet er lastet med ... samtidskunst. Visuel refleksion i "Kunststafetten" på Arken . Billedpadagogik Tidsskrift. Nr. 4: 2008a, 26-29 Illeris, Helene: Kunstlaboratoriet på Arken. Evalue- ringsrapport. Arken Museum for Moderne Kunst København: 2008b.

Illeris, Helene: Visual events and the friendly eye. Modes of educating vision in new educational settings in Danish art galleries. Museum and society. Vol. 7, nr. 1, 2009:16-31

Laigaard, Lene: Social Inclusion. En praksismodel for danske kunstmuseer? Nordisk Museologi. Nr. 1, 2005: 39-54

Lindberg, Anna Lena: Konstpedagogikens dilemma. Historiska rötter och moderna strategier. Studentlitteratur: Stockholm 1991

Nielsen, Frede V.: Almen Musikdidaktik. Akademisk Forlag: København 2007

Pierroux, Palmyre: Dispensing with Formalities in Art Education Research. Nordisk Museologi. Nr. 2, 2005: 76-88

Pierroux, Palmyre: Meaning, Learning and Art in Museums. A Situated Perspective. Faculty of Education. University of Oslo: Oslo 2007.

Roberts, Lisa C.: From Knowledge to Narrative. Educators and the Changing Museum. Smithsonian Institution Press: Washington 1997.

Roberts, Lisa C.: Curriculum Theory and Museum Education Practice. Remembering the Broader Context. Journal of Museum Education. Nr. 2, 2006: 77-78

Rose, Julia: Shared Journeys. Curriculum Theory and Museum Education. Journal of Museum Education. Nr. 2, 2006: 81-94

Rung, Mette Houlberg: Art Museums and Creative Citizens. Museological Review. Nr. 13, 2008: $1-10$

Samuelsen, Arne Marius: Kunstformidling for barn $i$ kunstmuseum og skole - med vekt på formidlerrollen. Universitetet i Bergen: Bergen 2003.

Schnack, Karsten: Er didaktik og curriculum det samme?

http://www.dpu.dk/everest/Publications/Medarbejdere/schnack/20051005174113/CurrentVersion/Er\%20didaktik\%20og\%20curricu- 
lum\%20det $\% 20$ samme.pdf Notat til studierejse 2000.

Slagstad, Rune; Korsgaard, Ove; Løvlie, Lars (red.): Dannelsens forvandlinger. Pax Forlag: Oslo 2003 Stær, Anja Lemcke: Videns-og erfaringsudveksling $i$ krydsfeltet mellem vark, folkeskolelarer og museumsformidler. En empirisk undersøgelse med udgangspunkt $i$ et didaktisk spil foretaget blandt 23 dansk-og billedkunstlarere i folkeskolen. Upubliceret speciale. Afdeling for Kunsthistorie, Institut for Æstetiske Fag, Aarhus Universitet. Århus 2009.

Vallance, Elizabeth: Museum Education as Curriculum: Four Models Leading to a Fifth. Studies in Art Education. Nr. 45, 2004: 343-358

Vallance, Elizabeth: Finding Order. Curriculum Theory and the Qualities of Museum Education. Journal of Museum Education. Nr. 2, 2006: 133142

Wertsch, James V.: Voices of Collective Remembering Cambridge University Press: Cambridge 2002.

Østbye, Guri Lorentzen Barn + Kunst = Danning. $\mathrm{Om}$ a fabulere og filosofere i kunstmøter. Gurilo Forlag: Oslo 2007
*Helene Illeris is Associate Professor of Art and Visual Culture at the Danish School of Education, Aarhus University(Denmark), and Professor II of Art Education at Telemark University College (Norway). She is also a project leader at the CAVIC (Contemporary Art and Visual Culture in Education) Nordic research network. Her research interests include gallery education with a special focus on contemporary art forms, social inclusion, aesthetic learning processes and practices of looking. For further information, see www.dpu.dklaboutlilleris.

Contact address: The Danish School of Education, Tuborgvej 164, DK-2400 Copenhagen NV

E-mail: illeris@dpu.dk 